\title{
Rational use of antibiotics for treatment of urinary infection in sows
}

\author{
Uso racional de antibióticos para tratamento de infecção urinária em porcas
}
Marcio José Bach ${ }^{1}$ (D) , Daiane Gullich Donin ${ }^{1}$ (D) , Sérgio Rodrigo Fernandes² (D) , Gabriela Berdusco Martins $^{3}$ (D) , Geraldo Camilo Alberton ${ }^{\star 1}$ (D)

'Universidade Federal do Paraná (UFPR), Palotina, PR, Brazil

2Universidade Estadual de Londrina (UEL), Londrina, PR, Brazil

${ }^{3}$ Primato agro-industrial cooperative, Toledo, PR, Brasil

${ }^{*}$ Correspondent: alberton@ufpr.br

Received

May 13, 2021.

Accepted

August 16, 2021.

Published

September 8, 2021.

www.revistas.ufg.br/vet visit the website to get the how to cite in the article page.

\begin{abstract}
The endemic character of urinary infections (UI) in sows makes collective antimicrobial therapies via feed a routine. This, however, generates sub-doses unable to heal and contribute to the selection of antibiotic-resistant bacteria. The use of individual therapy is the most appropriate procedure to be performed on animals with UI. With this study, we aimed to evaluate the occurrence of $\mathrm{UI}$ in sows housed in the western region of Paraná and the efficacy and cost-benefit of individual treatment. A total of 353 females were selected from five different herds, submitted to urine collection in the final third of pregnancy by spontaneous urination method. The samples were analyzed physically and chemically with the use of reagent strips, and the presence of nitrite was a determinant for positivity for UI. The animals with UI had urine submitted to a bacteriological evaluation, were treated with parenteral medication (marbofloxacin - single dose - $8 \mathrm{mg} / \mathrm{kg}$ ), and submitted to a new urine collection $24 \mathrm{~h}$ and $48 \mathrm{~h}$ after the first. UI was observed in $4.53 \%$ of the females evaluated (16/353). Escherichia coli and Streptococcus sp. were the most frequently isolated agents. Seven days after the use of marbofloxacin $87.5 \%(14 / 16)$ of the animals were negative for UI, which demonstrates the efficacy of UI parenteral control. The diagnosis associated with individual therapy at the expense of collective medication was highly cost-effective, made it possible to drastically reduce the number of medicated animals, and was efficient in controlling UI. Thus, it is concluded that it is possible to make rational use of antibiotics by treating only sows that are proven to be positive for UI. This reduces the number of unnecessarily medicated animals and reduces the cost due to the use of antimicrobials only in sick animals.
\end{abstract}

Keywords: urinary tract infection; prevalence; marbofloxacin; parenteral treatment.

\section{Resumo}

O caráter endêmico das infecções urinárias (IU) em porcas faz 
com que seja rotina o uso de terapias antimicrobianas coletivas via ração, as quais geram subdoses que não promovem a cura e contribuem para a seleção de bactérias resistentes aos antibióticos. 0 uso de terapia individual é procedimento mais adequado a ser realizado nos animais com IU. Com este estudo objetivou-se avaliar a ocorrência de IU em matrizes alojadas na região Oeste do Paraná e a eficácia e custo-benefício do tratamento individual. Foram selecionadas 353 fêmeas, de cinco rebanhos distintos, submetidas à coleta de urina no terço final da gestação pelo método de micção espontânea. As amostras foram analisadas física e quimicamente com o uso de tiras reagentes, sendo que a presença de nitrito foi determinante de positividade para IU. Os animais com IU tiveram a urina submetida a avaliação bacteriológica, foram tratados com medicação parenteral (marbofloxacina - dose única - $8 \mathrm{mg} / \mathrm{kg}$ ) e submetidos a nova coleta de urina $24 \mathrm{~h}$ e $48 \mathrm{~h}$ após a primeira. IU foi observada em 4,53\% das fêmeas avaliadas (16/353). Escherichia coli e Stretococcus sp. foram os agentes isolados com maior frequência. Sete dias após o uso da marbofloxacina 87,5\% (14/16) dos animais foram negativos para IU, o que demonstra a eficácia do controle parenteral da IU. O diagnóstico associado à terapia individual em detrimento da medicação coletiva apresentou custo-benefício altamente vantajoso, possibilitou reduzir drasticamente o número de animais medicados e apresentou eficiência no controle da IU. Desta forma se conclui que é possível fazer uso racional de antibióticos mediante o tratamento apenas de porcas comprovadamente positivas para IU. Isto reduz o número de animais medicados desnecessariamente e reduz o custo em função do uso de antimicrobianos apenas em animais enfermos.

Palavras-chave: infecção trato urinário; prevalência; marbofloxacina; tratamento parenteral.

\section{Introduction}

Pig farming is an activity that has undergone major changes in recent years concerning production intensification and genetic improvement. This made animals more demanding and sensitive to diseases, favoring the emergence of multifactorial diseases with a variety of pathogens involved in co-infection. Among these diseases, urinary tract infection (UI) stands out due to the economic impact generated on the herds because of the reproductive failures it causes in females ${ }^{(1,2)}$, reduction in the lifespan of sows, and damage to performance and health of piglets ${ }^{(3)}$, presenting correlation with an increase in the mortality rate of piglets until weaning and a decrease in litter weight due to the reduction in milk production in females affected by $\mathrm{UI}^{(4)}$. Studies carried out in Brazil in pig herds under a confinement system demonstrate that UI prevalence is high, ranging from $29.5 \%^{(5)}$ to $47 \%^{(6)}$ in the South region and $41.1 \%$ in farms located in the Central West region ${ }^{(2)}$. Among the various predisposing factors to UI in swine 
females, especially during the gestation phase in confinement, the following stand out: 1) permanence of females in facilities that can favor excessive perineum contamination by feces; 2 ) ingestion of reduced volume of water, with a consequent reduction in the volume of produced urine, which facilitates the ascent and bacteria adhesion to the mucosa of the urinary tract; 3 ) locomotor problems in females that hinder mobility and impact the volume of water ingested; 4) performing inadequate antimicrobial therapies in females that affect the normal microbiota of the urinary tract ${ }^{(7)}$.

$\mathrm{UI}$ is understood as the penetration and multiplication of the typically sterile region of the urinary tract by bacteria, with Escherichia coli, Streptococcus sp., Staphylococcus sp., and Enterococcus sp. as the most involved agents in the pathogenesis of the disease ${ }^{(8)}$. In most cases of infection by these bacteria, there is an absence of clinical signs, which makes the disease go unnoticed on farms ${ }^{(7)}$.

As many UI cases are not evidenced by clear signs, diagnosis through clinical examination is of limited value, and the use of diagnostic methods that enable affected female identification is extremely important. In this context, the diagnosis can be made by examining urine using reagent strips, as it is fast, practical, and reliable ${ }^{(6)}$. Among the parameters evaluated by the reagent strip, the presence of nitrite characterizes a female positive for $\mathrm{UI}$, since the nitrite test is used to indirectly detect bacteriuria(6).

As $\mathrm{UI}$ is an endemic disease in herds, it is common to practice collective drug treatment with antibiotics via feed (e.g., using chlortetracycline, at a dosage of $300 \mathrm{ppm}$ ), since this is a practical method and does not require an individual diagnosis. This type of therapy has negative results for the herd since all sows (positive or not for UI) are treated simultaneously, which may generate ineffectiveness in the treatment due to underdoses. In acute infection cases, sows are normally anorectic, so the animals do not consume the amount of feed necessary to supply the amount of antibiotics estimated to control the disease ${ }^{(9)}$. In addition, this routine procedure contributes to bacterial resistance, in addition to causing dysbiosis in the entire herd, making the sows even more sensitive to infections, as dysbiosis in the vaginal region favors the rise of pathogenic bacteria to the bladder ${ }^{(10)}$. Additionally, sow dysbiosis contributes to the establishment of dysbiosis in piglets, as the sows are the main sources of microbiota for the litter, which is contaminated by contact with the skin and mucous membranes, as well as by contact with feces and other secretions. Therefore, piglets born to sows undergoing antimicrobial therapy during pregnancy or maternity are more susceptible to illnesses in the nursery, rearing, and finishing stages(11). Thus, the ideal treatment is individual, via parenteral, in females identified as positive for $\mathrm{UI}^{(9)}$.

There are several antibiotics used in parenteral therapies, and depending on the halflife of the drug used, the treatment must be repeated, at least for three days. As this procedure is laborious, it can be interrupted before the end, which predisposes the animal to underdoses and can compromise the effectiveness of the treatment. Thus, the parenteral use of a drug that meets the SISAAB (single injection short-acting antibiotic) concept, short-duration antibiotics, a broad spectrum of action and single injection, used in high doses aiming to rapidly cure the animal with a minimum exposure time ${ }^{(12)}$ is a promising alternative for the treatment of $\mathrm{UI}$ on farms.

Marbofloxacin is a third-generation synthetic fluoroquinolone, developed for individual veterinary treatment ${ }^{(13)}$, with a high standard of sensitivity to the main bacterial agents 
that cause genitourinary, respiratory, and digestive tract diseases ${ }^{(14)}$. For pigs, it is indicated for the treatment of urinary tract and intestinal infections caused by sensitive strains of $E$. coli., among other indications. A single-dose regimen of marbofloxacin 8 $\mathrm{mg} / \mathrm{kg}$, $16 \%$ solution, was initially developed for the treatment of respiratory diseases ${ }^{(15)}$. A study carried out in cattle with marbofloxacin in a single injection showed that its use following the SISAAB concept was able to efficiently control respiratory disease and that, by breaking the vicious cycle of bacterial pulmonary infection with a high load of bactericidal antibiotics, natural defenses, and the commensal microbiota can recover and maintain the lung in homeostasis ${ }^{(15)}$. In pigs, the pharmacokinetic profile of marbofloxacin contained in a $16 \%$ concentrated solution showed that approximately $60 \%$ of the administered dose is eliminated in the urine, mainly as an unchanged drug ${ }^{(13)}$, which provides an efficient action in the urinary tract.

The rational treatment of bacterial diseases with antibiotics is intended for patients individually diagnosed with the infection, and to be successful in therapies, an accurate diagnosis must be carried out associated with the choice of antibiotics according to the sensitivity test ${ }^{(16)}$, which has not been routinely practiced to combat UI in pig farming.

This study hypothesizes that the diagnosis of $\mathrm{UI}$ associated with individual therapy in positive animals is cost-effective compared to collective therapy practiced on farms and is presented as rational use of antibiotics. In addition, therapy using a drug that meets the SISAAB concept is effective in controlling $\mathrm{UI}$ and makes it possible to reduce the use of antimicrobials in swine production.

The objective of this work was to evaluate the occurrence of UI in sows housed individually in confinement and to evaluate the effectiveness and cost-benefit of an individual treatment protocol using the SISAAB concept.

\section{Material and Methods}

The study was approved by the Ethics Committee on the Use of Animals at the Federal University of Paraná (CEUA/UFPR) under protocol number 44/2020. It was carried out in a cooperative in the West of Paraná State, from August/2019 to March/2020, in five similarly managed farms ( $n=3730$ sows) with females housed in individual cages, randomly selected concerning birth order and age for collecting urine samples. Samples were collected from 353 AgPic Camborough females, 4 being the average parturition order and $220 \mathrm{~kg}$ the average body weight (BW). All farms had individual cages, automated feeders, nursing nipple, and gutter type drinking fountains, climatecontrolled sheds, and natural ventilation. The amount and type of feed consumed by the animals during the experimental period followed the recommendations of the cooperatives to which the farms were linked, and met the requirements of animals in gestation. The feeding had $3.18 \mathrm{Mcal} / \mathrm{kg}$ of metabolizable energy, $13 \%$ of crude protein, $0.60 \%$ of phosphorus, $0.22 \%$ of sodium, and $0.71 \%$ of available lysine, on a dry matter (DM) basis. $10 \%$ of the females in the squad were collected from farms smaller than 1000 females, and 100 from farms larger than 1000 females. To know the number of UIpositive females close to birth, collections were made in the final third of gestation in asymptomatic females. 
Collections were performed using the spontaneous urination method, on different days in each farm, before dawn, and before the first treatment of the females, to ensure the collection of the first urine and to carry out many collections and in a short period. Collections started at 6 AM, when it was still dark in the premises, and lasted until 7 AM. To verify if there was a difference between the urination onset time in females with or without $\mathrm{UI}$, in one of the farms $(\mathrm{n}=56)$, one person was responsible for marking the time each female took to urinate after the lights were turned on. The time between turning on the light and urination was distributed as follows: up to 5 minutes, 5-10 minutes, 1015 minutes, 15-20 minutes, 20-30 minutes, 30-40 minutes, and over 40 minutes.

The lights were turned on after six people entered the gestation shed and collections were started as the females began to urinate. The first jet of each urine was discarded, the urine was collected in a disposable cup, placed on the wall behind each female, allowing the identification of animals. After all collections from each farm, the physical examination of urine was performed with macroscopic observations such as color (colorless, light yellow, dark yellow), odor (characteristic, ammoniacal), and turbidity (clear, turbid).

Samples were also analyzed for the absence and presence of blood and protein, $\mathrm{pH}$ (very acidic, acidic, very alkaline, alkaline), and nitrite. Nitrite and $\mathrm{pH}$ were analyzed by examining the reagent strip (Uriaction 10®, Labtest, Lagoa Santa, MG). Animals with positive nitrite were considered positive for urinary infection. To confirm the positivity, the samples were transferred to sterile vials, placed in an isothermal box with ice, and sent to the laboratory for bacteriological examination (isolation and bacterial counting according to Oliveira ${ }^{(17)}$ and Koneman ${ }^{(18)}$, and an antibiogram using methodology according to Watts ${ }^{(19)}$.

Animals identified as positive for $\mathrm{UI}$ with the reagent strip were immediately medicated intramuscularly with marbofloxacin (Forcyl $\AA^{\circledR}$, Vétoquinol, Lure, France), in the neck region, in a single dose of $8 \mathrm{mg} / \mathrm{kg}$ of BW. Marbofloxacin was the antibiotic chosen for treatment because it meets the SISAAB concept and because it is indicated for urinary tract infections treatment caused by sensitive strains of $E$. coli, the main agent involved in $\mathrm{UI}$ in pigs. These females were submitted to new urine collections at 24 and 48 hours after the first one.

Bacteriological examination and bacterial counts were performed on samples collected at hour zero (first collection), 24h (second collection), and 48h (third collection) after the first collection. Samples with bacterial counts equal to or greater than $10^{5} \mathrm{CFU} / \mathrm{ml}$ were considered positive for $\mathrm{UI}^{(7)}$.

For the cost-benefit analysis of individual diagnosis and treatment, the cost of urinalysis materials (reagent strip, collection bottles, and labor), and the cost of parenteral treatment (marbofloxacin, needle, syringe, and labor) were considered. These costs were compared with the use of antibiotic medication via feed for the entire flock and, for this purpose, the following antimicrobials were considered: chlortetracycline (Aurac $100 \AA$ ) at a dose of $3 \mathrm{~kg}$ per ton of feed (according to the instructions of the supplier), and florfenicol (Amphenor ${ }^{\circledR}$ ), at a dosage of $4 \mathrm{mg} / \mathrm{kg}$ of BW, as per the instructions of the supplier. The analysis was performed considering a scenario of a farm with 1000 
sows, in which all of them were submitted to urinalysis with a reactive strip in the last third of pregnancy in all reproductive cycles. Concerning antibiotics via feed, the use of feed containing preventive antibiotics was considered for all lactating sows, during the entire lactation phase, and in all reproductive cycles.

Data on the frequency of negative and positive UI sows per group of time elapsed for urination, bacterial count, and frequency of sows that excreted nitrite in the urine between 0 and 48 hours after medication with marbofloxacin were submitted to the Shapiro-Wilk normality test (PROC UNIVARIATE), which indicated that the variables were not normally distributed. Thus, data were analyzed using the following non-parametric tests (PROC NPAR1WAY): (1) Mann-Whitney test to compare the frequency of negative and positive UI sows within each urination time group; (2) Kruskal-Wallis test followed by the Nemenyi-Dunn test to compare bacterial count and frequency of sows positive for nitrites in urine between times 0, 24, and 48 hours after marbofloxacin administration. Statistical analyzes were performed using the Statistical Analysis System, version 9.0, considering a significance level of 0.05 in all analyses.

\section{Results and Discussion}

On the farm where the time elapsed between the turning on of the lights and the urination of females was observed $(n=56)$, and most females urinated quickly after the lights were turned on, and some already started urinating one minute after the entrance to the shed. Most females (55.4\%) urinated between 1 and 5 minutes after entering the shed (Table 1). There was no difference $(P>0.05)$ between UI-negative and Ul-positive females in the urination time groups, except for the 10-15 min time. Only one positive female urinated in this time interval and, given its representativeness within a small sample of animals diagnosed as positive $(n=10)$, resulted in a significant difference $(P<0.05)$ concerning negative animals. This difference, however, did not change the time profile for urination between UI negative and positive sows up to 15 minutes after the lights were turned on, since the proportion of animals in these groups that urinated up to this time was 63 and 70\%, respectively. Overall, the proportions of animals within each urination time group indicate that it is not possible to discriminate between UI negative and UI positive sows based on the time elapsed from turning on the lights inside the shed to the time of urinating. 
Table 1. Time elapsed between turning on the light and its relationship with the number of positive and negative animals for urinary infection

\begin{tabular}{cccccccc}
\hline \multirow{2}{*}{$\begin{array}{c}\text { Timin) } \\
\text { (min) }\end{array}$} & \multicolumn{2}{c}{ Total } & \multicolumn{4}{c}{ Negative animals } & \multicolumn{2}{c}{ Positive animals } & p-value \\
\cline { 2 - 6 } & $\mathbf{n}$ & $\mathbf{\%}$ & $\mathbf{n}$ & $\mathbf{\%}$ & $\mathbf{n}$ & $\%$ & \\
\hline Up to 5 & 31 & 55.36 & 26 & 56.52 & 5 & 50.00 & 0.7094 \\
\hline $5-10$ & 4 & 7.14 & 3 & 6.52 & 1 & 10.00 & 0.7013 \\
\hline $10-15$ & 1 & 1.79 & $0^{\mathrm{b}}$ & $0.00^{\mathrm{b}}$ & $1^{\mathrm{a}}$ & $10.00^{\mathrm{a}}$ & 0.0320 \\
\hline $15-20$ & 5 & 8.93 & 5 & 10.87 & 0 & 0.00 & 0.2789 \\
\hline $20-30$ & 4 & 7.14 & 3 & 6.52 & 1 & 10.00 & 0.7013 \\
\hline $30-40$ & 6 & 10.71 & 4 & 8.70 & 2 & 20.00 & 0.2992 \\
\hline Above 40 & 5 & 8.93 & 5 & 10.87 & 0 & 0.00 & 0.2789 \\
\hline Total & 56 & 100.00 & 46 & 100.00 & 10 & 100.00 & - \\
\hline
\end{tabular}

Different lowercase letters on the same line compare absolute $(n)$ and relative (\%) frequencies by the nonparametric Mann-Whitney $(\mathrm{P}<0.05)$.

Thus, the presence of infection does not delay urination onset, since at each time interval the percentage of negative and positive females that urinated was similar. This information is extremely relevant when it comes to the collection by spontaneous urination, as it is expected that females with UI take longer to urinate, which could underestimate the occurrence of $\mathrm{UI}$ in the herd if collections were made in a short period.

When the urine samples of the 353 females collected in the five farms were evaluated, the presence of nitrite was found in 16 analyzes representing $4.53 \%$ of the total analysis (Table 2).

In the chemical examination of the urine, it was observed that $99 \%$ presented blood absence (352/353), 87.54\% presented protein absence (309/353), and 59.21\% acidic $\mathrm{pH}$, ranging from 6.0 to $6.5(209 / 353)$.

Of the 16 Ul-positive females, most did not present blood (93.75\%) and urine protein (75\%), which demonstrates that these parameters are not determinants of the presence of UI.

On physical examination, light-yellow color predominated (65.44\%), clear appearance $(88.95 \%)$, and characteristic odor of the species (92.07\%). These results were found in positive and negative females for the presence of nitrite.

Among the 16 UI-positive females, $68.75 \%$ of the urine samples were light yellow, $18.75 \%$ dark yellow, and $12.5 \%$ colorless. These observations were also verified by Alberton et al.(5), after evaluating urine samples from 1745 sows, and among those 
Bach M J et al.

positive for $\mathrm{UI}$, found a predominance of a light-yellow color (62.5\%). Similar results were also described by Menin et al. ${ }^{(8)}$ and Oliveira ${ }^{(20)}$. Pôrto et al. ${ }^{(21)}$, on the other hand, verified that the urine of sows with UI tends to have a dark yellow color.

Table 2. Physicochemical and macroscopic urinary parameters of sows ( $\mathrm{n}-353)$ with and without urinary infection

\begin{tabular}{|c|c|c|c|c|c|c|}
\hline \multirow{2}{*}{ Parameter } & \multicolumn{2}{|c|}{ Total } & \multicolumn{2}{|c|}{ Negative animals } & \multicolumn{2}{|c|}{ Positive animals } \\
\hline & $\mathbf{n}$ & $\%$ & $n$ & $\%$ & $\mathbf{n}$ & $\%$ \\
\hline \multicolumn{7}{|l|}{ Nitrite } \\
\hline Negative & 337 & 95.47 & 337 & 100 & 0 & 0 \\
\hline Positive & 16 & 4.53 & 0 & 0 & 16 & 100 \\
\hline \multicolumn{7}{|l|}{ Blood } \\
\hline Absent & 352 & 99.71 & 337 & 100 & 15 & 93.75 \\
\hline Present & 1 & 0.29 & 0 & 0 & 1 & 6.25 \\
\hline \multicolumn{7}{|l|}{ Protein } \\
\hline Absent & 309 & 87.54 & 297 & 88.13 & 12 & 75.00 \\
\hline Present & 44 & 12.46 & 40 & 11.87 & 4 & 25.00 \\
\hline \multicolumn{7}{|l|}{$\mathrm{pH}$} \\
\hline Very acidic $(<6.0)$ & 22 & 6.23 & 20 & 5.93 & 2 & 12.50 \\
\hline Acid (6.0-6.5) & 209 & 59.21 & 198 & 58.75 & 11 & 68.75 \\
\hline Alkaline (7.0-7.5) & 114 & 32.29 & 113 & 33.53 & 1 & 6.25 \\
\hline Very alkaline (> 7.5) & 8 & 2.27 & 6 & 1.79 & 2 & 12.5 \\
\hline \multicolumn{7}{|l|}{ Color } \\
\hline Colorless & 32 & 9.07 & 30 & 8.90 & 2 & 12.5 \\
\hline Light yellow & 231 & 65.43 & 220 & 65.28 & 11 & 68.75 \\
\hline Dark yellow & 90 & 25.50 & 87 & 25.82 & 3 & 18.75 \\
\hline \multicolumn{7}{|l|}{ Turbidity } \\
\hline Clear & 314 & 88.95 & 305 & 90.50 & 9 & 56.25 \\
\hline Turbid & 39 & 11.05 & 32 & 9.50 & 7 & 43.75 \\
\hline \multicolumn{7}{|l|}{ Odor } \\
\hline Characteristic & 325 & 92.07 & 314 & 93.18 & 11 & 68.75 \\
\hline Ammoniacal & 28 & 7.93 & 23 & 6.82 & 5 & 31.25 \\
\hline
\end{tabular}

As for urine appearance, among females positive for $\mathrm{UI}, 56.25 \%$ were classified as clear and $43.75 \%$ as turbid. A similar result was described by Menin et al. ${ }^{(8)}$, that of the total urine samples from sows with clinical suspicion for UI, 19.4\% were classified as clear and among these $79.53 \%$ were positive for the disease. However, Alberton et al.(5) obtained the opposite result, $83.15 \%$ of the urine samples were considered turbid and among the turbid, $90.28 \%$ presented positivity for UI. 
Regarding the urine odor of UI-positive females, $68.75 \%$ had a characteristic odor of the species and $31.25 \%$ ammoniacal, corroborating the results obtained by Pôrto et al.(21) who described that $43.8 \%$ of females that urine presented ammonia odor were positive for Ul. Alberton et al. ${ }^{(5)}$ also found that $62.37 \%$ of the females that presented ammoniacal odor in urine were positive for Ul, as well as Menin et al. ${ }^{(8)}$ who found $66.04 \%$ of the samples with ammoniacal odor, among which $73.18 \%$ were positive for Ul.

Considering each farm separately, the occurrence ranged from absent to $17.85 \%$ positivity for nitrite (Table 3).

Table 3. Urinary infection diagnosed by the presence of nitrite in the reagent strips per farm collected

\begin{tabular}{cccc}
\hline \multirow{2}{*}{ Farm } & \multirow{2}{*}{ Number of samples } & \multicolumn{2}{c}{ Positive nitrite } \\
\cline { 3 - 4 } & & $\mathbf{n}$ & $\%$ \\
\hline 1 & 56 & 10 & 17.85 \\
2 & 60 & 3 & 5.00 \\
3 & 108 & 0 & 0.00 \\
4 & 50 & 1 & 2.00 \\
5 & 79 & 2 & 2.53 \\
Total & 353 & 16 & 4.53 \\
\hline
\end{tabular}

The prevalence of $\mathrm{UI}$ of up to $15 \%$ is classified as a mild problem, from 16 to $25 \%$ as a serious and evolving problem, and a chronic and very serious problem above $25 \%{ }^{(4)}$. According to this classification, $80 \%$ of farms have a mild problem and only one of them has a serious problem.

A remarkable difference in the occurrence of $U I$ was observed in the five farms studied, even though they were farms with similar facilities. As it is a multifactorial disease, the number of sows with $\mathrm{UI}$ in a herd is directly related to the risk factors present on the farm, the main ones being: hygiene quality of the facilities, diseases of the locomotor system, quality and quantity of water ingested, stressful situations, management during pregnancy, trauma, the physiological state of the sows, delivery order, delivery duration, and the number of employees ${ }^{(7)}$. With the results obtained, even without evaluating the risk factors in the farms, the increase in the rate of occurrence of $\mathrm{UI}$ in farm one is suspected to be associated with one of the factors mentioned above.

As for the urine $\mathrm{pH}$ of UI-positive females, $12.5 \%$ had very acidic $\mathrm{pH}(<6.0), 68.75 \%$ acidic $\mathrm{pH}(6.0-6.5), 6.25 \%$ alkaline $\mathrm{pH}(7.0-7.5)$, and $12.5 \%$ very alkaline $\mathrm{pH}(>7.5)$. These values are like those obtained by Alberton et al.(5) and Menin et al.(8), but divergent from what was expected, since the bacterial flora present in cases of UI have the urease enzyme, which makes it capable of transforming urea into ammonia and cause the alkalinization 
of urine $\mathrm{(}^{(4)}$. The $\mathrm{pH}$ results observed in this study were possibly influenced by the pathogenesis of UI. E. coli, the most frequently isolated bacterium (Table 4), has serotypes that do not express the virulence factors related to the urease enzyme ${ }^{(22)}$, which prevented the significant urea transformation into ammonia and, consequently, the alkalinization of urine.

Table 4. Isolated microorganisms, bacterial count, and nitrite (presence/absence) in urine samples from female swine $(n-16)$ positive for urinary infection at three collection times $(0,24$, and 48 hours) after administration of marbofloxacin.

\begin{tabular}{|c|c|c|c|c|c|c|c|}
\hline \multirow{2}{*}{ Animal } & \multirow{2}{*}{$\begin{array}{c}\text { Isolated } \\
\text { microorganism }\end{array}$} & \multicolumn{3}{|c|}{ Bacterial count (CFC/mL) } & \multicolumn{3}{|c|}{ Nitrite (+ or - ) } \\
\hline & & Oh & $24 h$ & $48 \mathrm{~h}$ & $\mathbf{O h}$ & $24 h$ & $48 h$ \\
\hline 1 & Escherichia coli & $4.5 \times 10^{6}$ & $<1.0 \times 10^{2}$ & $<1,0 \times 10^{2}$ & + & - & - \\
\hline 2 & Escherichia coli & $3.0 \times 10^{6}$ & $<1.0 \times 10^{2}$ & $<1,0 \times 10^{2}$ & + & - & - \\
\hline 3 & Escherichia coli & $3.8 \times 10^{6}$ & $8.9 \times 10^{6}$ & $9,0 \times 10^{4}$ & + & + & + \\
\hline 4 & Escherichia coli & $3.0 \times 10^{6}$ & $9.2 \times 10^{5}$ & $<1,0 \times 10^{2}$ & + & + & - \\
\hline 5 & Escherichia coli & $1.5 \times 10^{6}$ & $3.2 \times 10^{5}$ & $1,8 \times 10^{5}$ & + & + & + \\
\hline 6 & Escherichia coli & $5.0 \times 10^{5}$ & $7.0 \times 10^{4}$ & $<1,0 \times 10^{2}$ & + & + & - \\
\hline 7 & Escherichia coli & $<1.0 \times 10^{2}$ & $<1.0 \times 10^{2}$ & $<1,0 \times 10^{2}$ & + & - & - \\
\hline \multirow{2}{*}{8} & \multirow{2}{*}{$\begin{array}{l}\text { Escherichia coli } \\
\text { Staphylococcus sp. }\end{array}$} & $<1.0 \times 10^{2}$ & $<1.0 \times 10^{2}$ & $<1,0 \times 10^{2}$ & \multirow{2}{*}{+} & \multirow{2}{*}{-} & \multirow{2}{*}{-} \\
\hline & & $<1.0 \times 10^{2}$ & $<1.0 \times 10^{2}$ & $<1,0 \times 10^{2}$ & & & \\
\hline 9 & Escherichia coli & $1.8 \times 10^{6}$ & $<1.0 \times 10^{2}$ & $<1,0 \times 10^{2}$ & + & - & - \\
\hline 10 & Escherichia coli & $6.5 \times 10^{6}$ & $<1.0 \times 10^{2}$ & $<1,0 \times 10^{2}$ & + & - & - \\
\hline 11 & Streptococcus sp. & $2.7 \times 10^{5}$ & $1.2 \times 10^{4}$ & $<1,0 \times 10^{2}$ & + & - & - \\
\hline 12 & Escherichia coli & $8.0 \times 10^{4}$ & $5.2 \times 10^{4}$ & $<1,0 \times 10^{2}$ & + & - & - \\
\hline 13 & Streptococcus sp. & $3.2 \times 10^{5}$ & $<1.0 \times 10^{2}$ & $<1,0 \times 10^{2}$ & + & - & - \\
\hline 14 & Escherichia coli & $3.2 \times 10^{5}$ & $<1.0 \times 10^{2}$ & $<1,0 \times 10^{2}$ & + & - & - \\
\hline \multirow{2}{*}{15} & \multirow{2}{*}{$\begin{array}{l}\text { Escherichia coli } \\
\text { Staphylococcus sp. }\end{array}$} & $1.1 \times 10^{7}$ & $<1.0 \times 10^{2}$ & $<1,0 \times 10^{2}$ & \multirow{2}{*}{+} & \multirow{2}{*}{-} & \multirow{2}{*}{-} \\
\hline & & $<1.0 \times 10^{2}$ & $<1.0 \times 10^{2}$ & $<1,0 \times 10^{2}$ & & & \\
\hline 16 & Escherichia coli & $1.1 \times 10^{7}$ & $<1.0 \times 10^{2}$ & $<1,0 \times 10^{2}$ & + & - & - \\
\hline \multicolumn{2}{|c|}{ Average/ Relative frequency (\%) } & $3.0 \times 10^{6 a}$ & $6.4 \times 10^{5 b}$ & \multicolumn{3}{|c|}{$1.7 \times 10^{4 \mathrm{~b}} 100,00^{\mathrm{a}} 25,00^{\mathrm{b}}$} & $12,50^{\mathrm{b}}$ \\
\hline \multicolumn{2}{|c|}{$p$ value } & \multicolumn{3}{|c|}{$P<0.0001$} & \multicolumn{3}{|c|}{$P<0.0001$} \\
\hline
\end{tabular}

Mean bacterial count and relative frequency values for the presence of nitrite $(+)$ in urine followed by different lowercase letters, differ by the Nemenyi-Dunn test $(P<0.05)$.

E. coli was isolated in $87.50 \%(14 / 16)$, and Streptococcus sp. was found in $12.50 \%(2 / 16)$, that is, $100 \%$ of the 16 urine samples positive for $\mathrm{UI}$ in the first collection had isolation 
of microorganisms of enteric origin. Of the positive ones, $87.50 \%(14 / 16)$ was isolated as pure culture and $12.50 \%(2 / 16)$ as mixed culture in association with Staphylococcus sp. Like what occurs in humans, where more than $80 \%$ of UI are caused by uropathogenic $E$. coli(23), the microbiota involved in UI in pigs had a predominance of $E$. coli., which corroborates several studies that isolated this agent in most of the urine samples evaluated, with the positivity of $90.62 \%{ }^{(24)}$, and $89.50 \%(25)$.

The reagent strip specificity was 77.3\%; of the 22 nitrite-positive urine samples collected between 0 and 48 hours after application of marbofloxacin, five samples had a bacterial count lower than $10^{5} \mathrm{CFU} / \mathrm{ml}$ (animals 3, 6, 7, 8, and 12; Table 4). Urine samples from female swine with a bacterial count of $10^{4} \mathrm{CFU} / \mathrm{ml}$ are considered suspicious for UI, while those equal to or above $10^{5} \mathrm{CFU} / \mathrm{ml}$ are considered indicative of $\mathrm{UI}^{(4)}$. The test strip specificity observed in the present study was lower than that obtained by Mazutti et al. ${ }^{(6)}$, that by comparing nitrite strip test and full urinalysis, found that 73 positive samples for nitrite in the test strip showed bacterial counts above $10^{5}$ $\mathrm{CFU} / \mathrm{ml}$, that is, $100 \%$ of specificity. On the other hand, Bellino et al. ${ }^{(26)}$ concluded that the test with the reagent strip is inefficient for diagnosing chronic forms of UI. In that study, the presence of nitrite was positive in few samples, but the agents causing the infections were largely non-specific bacteria from the intestinal tract. Another fact observed by these authors was the high prevalence of Actinobaculum suis, an agent that does not transform nitrate into nitrite.

There was a reduction $(P<0.05)$ in bacterial counts and the presence of nitrite in urine 24 and 48 hours after the application of marbofloxacin (Table 4). After 24 hours of medication, 12 samples were negative in the test strip, and 10 samples had bacterial counts below 104; 48 hours after the medication, 14 samples were negative for the reagent strip and presented a bacterial count lower than $10^{4}$, indicating the efficiency of marbofloxacin in $87.50 \%$ of the treated animals.

The four samples that had no reduction in bacterial counts were sent to the laboratory for assessment of their sensitivity to marbofloxacin, in the first and second collections. Of these, two (50\%) had isolation of Escherichia coli, and two (50\%) had isolation of Streptococcus sp. In the first collection, three (75\%) of the samples were sensitive to marbofloxacin and one (25\%) was resistant. In the second collection, one $(25 \%)$ of the sensitive samples showed intermediate sensitivity; one (25\%) that was resistant in the first collection was sensitive in the second; the other two (50\%) had no growth in the second collection. These results converge to the result presented by the reactive strip because in the second collection all the results of these animals were negative in the strip examination and had no bacterial growth in the laboratory, or had counts below $10^{4} \mathrm{CFU} / \mathrm{ml}$ and were sensitive to marbofloxacin in the antibiogram. Females that remained with high bacterial counts after treatment were of advanced age, and showed resistance to the action of the antibiotic chosen for the treatment.

All the evaluated farms had as routine management the use of collective antimicrobial therapy (florfenicol or amoxicillin) via feed, twice a year. The females had been medicated in April/2019, and collections were carried out from August/2019 to March/ 2020. In the normal protocol of the farms, females would be collectively treated again in October/2019. A systematic literature review to investigate the effectiveness of oral administration of antibiotics to pigs indicated that this practice increases the risk of 
antimicrobial resistance of $E$. coli in this species(27), which could be observed in two of the 16 UI-positive females (animals 3 and 5; Table 4).

After the presentation of the first results of urine collection and assessments, the five farms under study immediately opted to no longer carry out collective medications via feed. Regarding the active principles chosen for collective therapies, Mazutti et al. ${ }^{(28)}$ used $2 \%$ florfenicol for the treatment of sows with UI for the treatment of $E$. coli infections and obtained unsatisfactory results, as the drug promoted a significant reduction in the bacterial count in the treated group, but not in the positivity of medicated females.

As $E$. coli can invade epithelial cells of the bladder and form intracellular bacterial colonies, evading the immune system, and traditional microbial therapies ${ }^{(29)}$, the use of a SISAAB antibiotic - antibiotic in high dosage and single administration - showed, in the present study, efficiency in the treatment of UI (in $87.50 \%$ of females). Females treated with marbofloxacin showed a decrease in UI after a short exposure time (48 hours) to this antibiotic, which is advantageous, as it allows the action of natural immunity to be privileged after the infection is interrupted ${ }^{(12)}$. In practice, this therapy eliminates sensitive bacterial populations and possible resistant bacterial subpopulations present in the infectious process.

Collective treatment via feed for pregnant and lactating females is widely used due to its practicality, and the absence of the need for individual diagnosis. However, this method may not be the most appropriate, since all sows (with or without UI) are treated simultaneously, the choice of antibiotic is not based on the microbial sensitivity profile involved, and the dose used is not always the most adequate, contributing to the selection of resistant microorganisms ${ }^{(30,31)}$, and imbalance of the normal microbiota of these animals ${ }^{(9)}$. Collective treatment via feed with chemotherapy and urine acidifiers is suggested when the prevalence of $\mathrm{UI}$ is above $16 \%{ }^{(4)}$. The results of the present study show that $95.47 \%$ of the females would be treated unnecessarily, with only one farm showing positivity above $16 \%$ and, even in this one, $82.15 \%$ had a negative result (Table 3 ). It is hard to define from which percentage a collective treatment could be indicated since the ideal is not to medicate anyone needlessly.

Comparing the economic viability of using antibiotics in a herd of one thousand sows, medicating lactating females with florfenicol, the cost per year is BRL 24,314.90, with limited efficiency ${ }^{(28)}$. With the use of chlortetracycline, the cost is BRL 36,753.75. With the use of reactive strips in $100 \%$ of females, the cost is BRL 1,710.00 added to the cost of medication with marbofloxacin in positive females, in this case, $4.53 \%$ of females, with an expense of BRL 2,588.65, totaling BRL 4,298.65. Thus, the savings generated are BRL 32,455.09 per year (88.30\%), and only positive females are exposed to the medication, reducing the selection pressure of antibiotic-resistant bacteria, and reducing the negative impact on the microbiota of sows and piglets.

If we take into consideration the prevalence of UI on farms, the cost-benefit is advantageous even on farms with a very severe prevalence, above $25 \%$ (Table 5). 
Table 5. Cost-benefit of using individual diagnosis according to the prevalence of urinary tract infection on farms, estimated for a sounder of one thousand females

\begin{tabular}{|c|c|c|c|c|}
\hline \multirow{2}{*}{$\begin{array}{l}\text { Prevalence } \\
\text { (\%) }\end{array}$} & \multicolumn{3}{|c|}{ Costs with individual treatment (BRL) } & \multirow{2}{*}{$\begin{array}{c}\text { Difference between } \\
\text { individual and } \\
\text { collective treatment } \\
\text { with } \\
\text { chlortetracycline } \\
\text { (BRL) }\end{array}$} \\
\hline & $\begin{array}{l}\text { Reactive strip } \\
\text { for all females }\end{array}$ & $\begin{array}{c}\text { Medication with } \\
\text { marbofloxacin on all } \\
\text { positive females }\end{array}$ & Total & \\
\hline 15 & $1,710.00$ & $8,571.68$ & $10,281.68$ & $26,472.07$ \\
\hline 25 & $1,710.00$ & $14,286.15$ & $15,996.15$ & $20,757.60$ \\
\hline 35 & $1,710.00$ & $20,000.58$ & $21,710.58$ & $15,043.16$ \\
\hline
\end{tabular}

\section{Conclusion}

Pig farms can reduce or even eliminate the use of collective antibiotics in the feed, replacing them with the use of marbofloxacin in a single dose and high dosage $(8 \mathrm{mg} / \mathrm{kg}$ of BW), a treatment that is efficient and cost-effective in farms with different prevalence of Ul.

Rational use of antibiotics for the treatment of $\mathrm{UI}$ in sows is possible and viable by applying a precise diagnosis to know the occurrence of the disease on farms, identifying the positive animals, and treating only affected animals.

\section{Conflict of interests}

The authors declare no conflict of interest.

\section{References}

1. Blomström A-L, Ye $X$, Fossum $C$, Wallgren $P$, Berg $M$. Characterisation of the virome of tonsils from conventional pigs and specific pathogen-free pigs. Viruses. 2018. 10(7): 382.

2. Moura R de, Caldara FR, Foppa L, Machado SP, Nääs I de A, Garcia RG, Gonçalves LMP. Correlation between urinary tract infection and reproductive performance of sows. Revista Brasileira de Zootecnia. 2018. 47: e20180073. 1-5.

3. Pascoal LM, Chagas SR, Dall'Agnol M, Fioravanti MCS, Matos MPC, Teixeira WFP, Sobestiansky Y. The influence of infection in the urinary tract of sows on arthritis, facial lesions and weight gain in suckling 
piglets. Research, Society and Development. 2020. 9(10): e9779109166-e9779109166. 1-13. DOI: https:/ /doi.org/10.33448/rsd-v9i10.9166.

4. Alberton GC, Sobestiansky J, Donin DG. Infecção urinária em fêmeas em produção. In: Sobestiansky J. \& Barcellos D. Doenças dos Suínos. 2ª ed. Goiânia: Cânone Editorial; 2012. p. 179-94. Português.

5. Alberton GC, Werner PR, Sobestiansky J, Costa OD, Júnior WB. Prevalência de infecção urinária e de Actinomyces suis em porcas gestantes e sua correlação com alguns parâmetros físicos e químicos da urina. Archives of Veterinary Science. 2000. 5(1): 81-88. DOl:http://dx.doi.org/10.5380/avs.v5i1.3890

6. Mazutti K, Locatelli-Dittrich R, Lunardon I, Kuchiishi SS, Lara AC de, Zotti E, Alberton GC. Evaluation of the reagent test strips and microscopic examination of urine in the diagnosis of urinary tract infection in sows. Pesquisa Veterinária Brasileira. 2013. 33(9): 1103-1108. Available on https://www.scielo.br/j/pvb/ a/sq9ncVYW9brGGxt36QTNQPC/?format=pdf\&lang=pt

7. Fairbrother JM. Urinary tract infection. In: Straw BE, Zimmerman JJ, D'Allaire S, Taylor DJ. Diseases of Swine. Blackwell Publ Ames. 2006. p. 671-4.

8. Menin Á, Reck C, Capelli JC, Ferraz SM, Vaz EK. Diagnóstico de infecção urinária em fêmeas suínas produtivas em granjas comerciais no sul do Brasil. Ciência Animal Brasileira. 2008. 9(1): 197-206. Available on https://www.revistas.ufg.br/vet/article/view/3679.

9.Alberton GC, Locatelli-Dittrich R. Infecções do trato urinário em porcas. In: Alfieri AF, Barry AF, Alfieri AA, Silva CA, Dallanora D, Zotti E, Alberton GC, Rodrigues IMTC, Machado IP, Griessler K, Mores MAZ, Dittrich RL \& Starkl V (Eds), Tópicos em Sanidade e Manejo de Suínos Curuca Consciência Ecológica, São Paulo. 2010. p. 83-135.

10.Merk K, Borelli C, Korting HC. Lactobacilli-bacteria-host interactions with special regard to the urogenital tract. International Journal of Medical Microbiology. 2005. 295(1): 9-18. DOI: https://doi.org/ 10.1016/j.ijmm.2004.11.006.

11. Looft T, Johnson TA, Allen HK, Bayles DO, Alt DP, Stedtfeld RD, Sul WJ, Stedtfeld TM, Chai B, Cole JR, Hashsham AS, Tiedje JM, Stanton TB . In-feed antibiotic effects on the swine intestinal microbiome. Proceedings of the National Academy of Sciences 2012. 109(5): 1691-1696. DOI: https://doi.org/10.1073/ pnas.1120238109

12. Grandmange E, Giboin H, Schneider M, El-Garch F, Oxley S, Woehrlé F. Single-injection short-acting antibiotic (SISAAB) for the treatment of acute coliform mastitis. Cattle Practice. 2012. 20(3): 199-201.

13. Schneider M, Paulin A, Dron F, Woehrlé F. Pharmacokinetics of marbofloxacin in pigs after intravenous and intramuscular administration of a single dose of $8 \mathrm{mg} / \mathrm{kg}$ : dose proportionality, influence of the age of the animals and urinary elimination. Journal of Veterinary Pharmacology and Therapeutics. 2014. 37(6): 523-30.

14. Yang F, Liu Y, Li Z, Wang Y, Liu B, Zhao Z, Zhou B, Wang, G.. Tissue distribution of marbofloxacin in pigs after a single intramuscular injection. Journal of Veterinary Science. 2017. 18(2): 169-73.

15. Vallé M, Schneider M, Galland D, Giboin H, Woehrlé F. Pharmacokinetic and pharmacodynamic testing of marbofloxacin administered as a single injection for the treatment of bovine respiratory disease. Journal of Veterinary Pharmacology and Therapeutics. 2012. 35(6): 519-28.

16. Walger P. Rational use of antibiotics. Internist (Berl). 2016. 57(6): 551-68.

17. Oliveira SJ. Microbiologia veterinária: guia bacteriológico prático. Canoas. Ed da Ulbra. 2000.

18. Koneman E, Winn Jr W, Allen S, Janda W, Procop G, Schreckenberber P, Woods G. Diagnóstico microbiológico: texto e atlas colorido. In: Diagnóstico microbiológico: texto e atlas colorido. 2012. p. xxxv-1565. Disponível em: https://pesquisa.bvsalud.org/portal/resource/pt/lil-695482

19. Watts JL. Performance Standards for Antimicrobial Disk and Dilution Susceptibility Tests for Bacteria Isolated from Animals: Second Informational Supplement. Clinical and Laboratory Standards Institute; 2013.

20. Oliveira FH de. Aspectos físico-químicos e microbiológicos da urina, pH e consistência das fezes de 
matrizes suínas suplementadas com ácido cítrico e cloreto de amônio. Universidade Federal de Goiás. 2010. Disponível em: http://repositorio.bc.ufg.br/tede/handle/tde/938

21. Pôrto RNG, Sobestiansky J, Matos MPC, Gambarini ML. Aspectos físicos químicos e microbiológicos da urina de matrizes suínas descartadas. Ciência Rural. 2003. 33(2): 319-324. DOI: https://doi.org/ 10.1590/S0103-84782003000200021

22. Kaper JB, Nataro JP, Mobley HLT. Pathogenic Escherichia coli. Nature Reviews Microbiology. 2004. 2(2): 123-40.

23. Silverman JA, Schreiber HL IV, Hooton TM, Hultgren SJ. From physiology to pharmacy: developments in the pathogenesis and treatment of recurrent urinary tract infections. Current Urology Reports. 2013. 14(5): 448-56.

24. Mazutti K, Alberton GC, Ferreira FM, Lunardon I, Zotti E, Weber S. Efeito do extrato de oxicoco no tratamento de infecções do trato urinário em porcas. Archives of Veterinary Science. 2012. 17(2): 1-9.

25. Merlini LS, Vieira GFP, Cardoso MB, Begotti IL, da Silva ALG, da Silva Barbosa VH. Diagnóstico de infecção urinária em fêmeas suínas produtivas em granjas comerciais no município de Umuarama, Paraná, Brasil. Enciclopédia Biosfera, Centro Científico Conhecer - Goiânia. 9(16): p732-741.

26. Bellino C, Gianella P, Grattarola C, Miniscalco B, Tursi M, Dondo A, D'Angelo A, Cagnasso A. Urinary tract infections in sows in Italy: accuracy of urinalysis and urine culture against histological findings. Veterinary Record. 2013. 172(7): 183.

27. Burow E, Simoneit C, Tenhagen B-A, Käsbohrer A. Oral antimicrobials increase antimicrobial resistance in porcine $E$. coli--a systematic review. Preventive Veterinary Medicine. 2014. 113(4): 364-75.

28. Mazutti K, Noleto Aguiar T, Zotti E, Montiani-Ferreira F, Alberton GC. Eficácia do florfenicol no tratamento de infecções do trato urinário em porcas. Revista Acadêmica Ciência Animal. 2013. 11(1): 6573.

29. Scott VCS, Haake DA, Churchill BM, Justice SS, Kim J-H. Intracellular bacterial communities: a potential etiology for chronic lower urinary tract symptoms. Urology. 2015. 86(3): 425-31.

30. Drummond VO, Perecmanis S. Enterotoxin genes and antimicrobial profile of Escherichia coli isolated from healthy swines in Distrito Federal, Brazil. Arquivo Brasileiro de Medicina Veterinária e Zootecnia. 2013. 65(4):1005-9.

31. Jiang H-X, Lü D-H, Chen Z-L, Wang X-M, Chen J-R, Liu Y-H, Liao XP, Liu JH, Zeng ZL. High prevalence and widespread distribution of multi-resistant Escherichia coli isolates in pigs and poultry in China. The Veterinary Journal. 2011. 187(1): 99-103. 